\title{
REPARAÇÃO E REABILITAÇÃO DE ESTRUTURAS PORTUÁRIAS COM REDUZIDO IMPACTO AMBIENTAL: O CASO DO PORTO DE ABRIGO DA ILHA DO PORTO SANTO (MADEIRA, PORTUGAL)
}

\author{
Repair and rehabilitation of harbor structures with reduced environmental impact: \\ The case of the shelter harbor of Porto Santo Island (Madeira, Portugal)
}

Nuno Miguel Barros de Sousa ${ }^{1}$, Luiz Guerreiro Lopes ${ }^{2}$

Recebido em 10 de agosto de 2017; aceito em 18 de setembro de 2017; disponível on-line em 26 de abril de 2018.

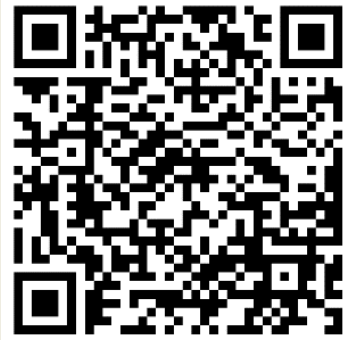

PALAVRAS CHAVE:

Reabilitação estrutural;

Estruturas portuárias;

Quebra-mares;

Estruturas de acostagem;

Porto do Porto Santo.

KEYWORDS:

Structural rehabilitation;

Harbor structures;

Breakwaters;

Quay wall structures;

Porto Santo's harbor.

* Contato com os autores:

${ }^{1}$ e-mail: nunmbs@gmail.com ( N. M. Barros de Sousa )

Licenciado e Mestre em Engenharia Civil pela Universidade da Madeira, Portugal.

2e-mail: lopes@uma.pt ( L. Guerreiro Lopes )

Prof. Doutor, Faculdade de Ciências Exatas e da Engenharia, Universidade da Madeira, Funchal, Madeira, CIMO/ESA-IPB, Bragança, e ICAAM/UE, Évora, Portugal.
RESUMO: Neste trabalho, são descritas e analisadas as diversas soluções implementadas nas obras de reparação e reabilitação do porto de abrigo da llha do Porto Santo, no Arquipélago da Madeira, Portugal. São focados os aspectos essenciais envolvidos nos trabalhos de reabilitação, como o enquadramento climático e geográfico, os estudos preliminares realizados, a caracterização das obras e a solução de reabilitação implementada, que contribuiu para a redução do seu impacto ambiental, assim como a ordem de trabalhos e os meios necessários à sua execução. São também apresentados os resultados da aplicação da metodologia simplificada de cálculo das dimensões e do peso dos blocos de proteção e do enrocamento, bem como da espessura das diferentes camadas por estes formadas, sendo ainda discutidos os aspectos mais e menos positivos desses trabalhos de reabilitação portuária.

ABSTRACT: In this paper, the different solutions implemented in the repair and rehabilitation works of the shelter harbor of Porto Santo Island, in the Archipelago of Madeira, Portugal are described and analyzed. The essential aspects involved in the rehabilitation works are focused, such as the climatic and geographical framework, the preliminary studies carried out, the characterization of the works and the rehabilitation solution implemented, which contributed to the reduction of their environmental impact, as well as the task schedule and the means for its execution. The results of the application of the simplified methodology for calculating the dimensions and weight of the protection blocks and the rockfill, as well as the thickness of the different layers formed by them are also presented, and the most positive and the less positive aspects of these harbor rehabilitation works are also discussed. 


\section{INTRODUÇÃO}

A análise dos impactos ambientais das obras de engenharia e construção civil, bem como a correta avaliação dos fatores ambientais que sobre as mesmas atuam, assumem maior relevância nas regiões mais expostas as intempéries e às consequências dos fenómenos naturais extremos, nomeadamente num cenário de aparente aumento da frequência e da intensidade de tais eventos extremos (BROWN et al., 2010) em decorrência do aquecimento global e das alterações climáticas.

Esse é o caso do Arquipélago da Madeira, situado no Oceano Atlântico Nordeste - que política e administrativamente constitui a Região Autónoma da Madeira - cujas duas únicas ilhas habitadas, Madeira e Porto Santo, são suscetíveis aos efeitos adversos de tais eventos extremos.

Num contexto como esse, e tratando-se de uma região insular que tem o turismo, assente principalmente na natureza e na paisagem, como pilar central da sua economia e motor do seu desenvolvimento, assumem particular relevância as obras de engenharia costeira e portuária nas quais exista não apenas uma especial atenção às suas condicionantes ambientais, mas também uma preocupação com a minimização dos seus impactos no ambiente envolvente e na paisagem.

Esse é o caso das obras de reabilitação do porto de abrigo da Ilha do Porto Santo, objeto deste estudo, que constituem um interessante exemplo, no que se refere a intervenções de natureza estrutural, da execução de trabalhos de engenharia com reduzido impacto ambiental, envolvendo o reaproveitamento de materiais, a preservação da paisagem e a execução faseada dos trabalhos, de modo a minimizar o seu impacto sobre o meio envolvente e manter a operacionalidade do porto.

Como é fundamental a extensão do tempo de vida operacional das infraestruturas portuárias devido à sua importância crucial, nomeadamente em termos económicos, comerciais e logísticos, e como a reparação localizada das áreas degradadas ou danificadas das estruturas portuárias, em particular daquelas de betão armado, como regra não constitui uma solução adequada de longo prazo, torna-se necessário avaliar a extensão e o tipo de danos e as suas causas e realizar trabalhos de reabilitação de maior envergadura, adequados às estruturas em causa (TAYLOR; DAVIS, 2002).

Isso faz com que a reabilitação de estruturas portuárias seja um trabalho complexo, com elevados custos, que demanda tempo e recursos materiais e humanos adequados, exigindo um elevado nível de capacitação técnica e de otimização das atividades a serem executadas, como se depreende deste estudo, que apresenta uma descrição detalhada e uma apreciação crítica das obras de reparação e reabilitação do porto de abrigo adotadas como caso de estudo.

O porto de abrigo da llha do Porto Santo é uma estrutura portuária originalmente construída na primeira metade da década de 1980 e posteriormente ampliada de modo a poder atender as necessidades decorrentes do desenvolvimento da região onde está implantada.

0 referido porto destina-se fundamentalmente à acostagem de navios de cruzeiro e do navio ferry que assegura a ligação regular inter-ilhas, permitindo o transporte de passageiros, veículos e mercadorias entre a llha da Madeira e o Porto Santo, bem como à atracagem e operação de navios de transporte de carga contentorizada e de carga sólida a granel.

A requalificação das infraestruturas portuárias da llha do Porto Santo, apoiada por fundos europeus do QREN (Quadro de Referência Estratégico Nacional) e iniciada em 2007 com as obras de reparação e reabilitação das estruturas de proteção e acostagem aqui descritas, foi concluída apenas no final de 2015.

Neste artigo, descreve-se o estado das estruturas de acostagem e de proteção portuária previamente existentes, os estudos preliminares e diagnósticos realizados visando a sua recuperação, o planeamento das obras objetivando reduzir o seu impacto ambiental e, simultaneamente, salvaguardar a operacionalidade do porto e evitar a 
sua interrupção durante os trabalhos de reparação, os métodos construtivos adotados, os tipos e as quantidades de materiais empregues, bem como os meios materiais e humanos mobilizados.

\section{CARACTERIZAÇÃO DA ESTRUTURA PORTUÁRIA E DO MEIO FÍSICO ENVOLVENTE}

\section{1 ÁREA DE ESTUDO E ZONA DE IMPLANTAÇÃO DA OBRA}

A Ilha do Porto Santo, localizada a NE da Ilha da Madeira, no Atlântico Nordeste $\left(33^{\circ} 04^{\prime} \mathrm{N}\right.$, $16^{\circ} 21^{\prime} \mathrm{W}$ ), e desta distante cerca de $42 \mathrm{~km}$ em linha reta, possui uma área de $40,7 \mathrm{~km}^{2}$ e um perímetro de 48,3 km (ROCHA et al., 2002), sendo a segunda maior ilha do Arquipélago da Madeira, uma das áreas insulares que integram a região biogeográfica da Macaronésia (LLORIS et al., 1991).

A ilha, com cerca de $12 \mathrm{~km}$ de comprimento e $5 \mathrm{~km}$ de largura máxima, apresenta, na sua costa SE, uma praia arenosa com cerca de 9 km de extensão - cujas águas tépidas e areias finas e amarelo-douradas com propriedades terapêuticas, associadas a um clima ameno e temperado, dão notoriedade à Ilha do Porto Santo como destino turístico de lazer e de saúde e bemestar - , estando o porto de abrigo objeto deste estudo localizado na sua zona nascente $\left(33^{\circ} 03,5^{\prime} \mathrm{N}\right.$, $\left.16^{\circ} 19^{\prime} \mathrm{W}\right)$.

A llha do Porto Santo situa-se numa zona oceânica sujeita às altas pressões atmosféricas do sistema subtropical semipermanente do Oceano Atlântico Norte, responsável pela predominância dos ventos alísios de NE na região (CROPPER; HANNA, 2014).

Como o vento é uma condicionante da dinâmica oceânica, importa salientar que na região em estudo os ventos dominantes são de rumo norte, sendo mais intensos os do quadrante oeste. Com base em dados recolhidos entre 1961 e 1990, constatou-se que é no mês de janeiro que se verifica a maior intensidade do vento (SILVA, 2002), sendo de $16 \mathrm{~km} / \mathrm{h}$ o valor médio máximo registado no referido período.

Nessa região insular, tempestades com origem e desenvolvimento no Atlântico Norte têm produzido fortes precipitações, ventos muito intensos e forte agitação marítima, com consequências por vezes danosas para as estruturas de proteção costeira e portuária aí existentes, sendo a segurança da navegação no acesso ao porto de abrigo do Porto Santo, assim como a sua operacionalidade, fortemente dependentes das condições meteorológicas e do estado do mar vigentes.

Eventos de precipitação muito intensa têm sido responsáveis, na região em estudo, pela ocorrência de cheias rápidas, deslizamentos de terras e fluxos de detritos, algumas vezes catastróficos (FRAGOSO et al., 2012), que arrastam grandes volumes de material sedimentar e de detritos rochosos e lenhosos do interior em direção à costa, causando assoreamento em áreas próximas às estruturas costeiras e portuárias nela existentes.

Por sua vez, ventos muito intensos associados a baixas pressões atmosféricas - e a forte agitação marítima têm provocado, nessa região, a sobre-elevação do nível do mar e situações de intenso galgamento das estruturas de proteção costeira.

Refira-se, a título de exemplo, os grandes danos ao quebra-mar de proteção da Marina do Lugar de Baixo $\left(32^{\circ} 40,5^{\prime} \mathrm{N}, 17^{\circ} 05,5^{\prime} \mathrm{W}\right)$, na vizinha Ilha da Madeira, obra concluída em 2004 e parcialmente destruída já no ano seguinte (REIS et al., 2014), tendo sido posteriormente reparada e novamente seriamente afetada por eventos extremos ocorridos nos anos de 2006, 2009, 2010 e 2013, levando à sua completa inoperabilidade e, mais recentemente, à conclusão de não ser mais economicamente viável a sua recuperação.

Tratando-se de uma área insular, as correntes oceânicas exercem igualmente enorme influência no clima do Porto Santo, sendo predominantes na região as correntes dos Açores e das Canárias (SALA et al., 2013).

As marés são do tipo semidiurno regular (RAMOS, 2009), acontecendo de forma quase simultânea em todo o Arquipélago da Madeira. 
Para além dos ventos e das correntes marítimas e da localização afastada dos continentes africano e europeu - situando-se a cerca de 640 $\mathrm{km}$ da costa marroquina e $800 \mathrm{~km}$ da costa sul de Portugal continental - , outros fatores também condicionam de forma significativa o clima do Porto Santo, incluindo o relevo, a altitude, a reduzida dimensão da ilha e a sua exposição aos fatores ambientais (SILVA, 2002).

\subsection{DESCRIÇÃO DA ESTRUTURA PORTUÁRIA EXISTENTE}

O porto de abrigo da Ilha do Porto Santo é constituído por um molhe principal, com cais acostável no bordo interior, e um contra molhe de menores dimensões, igualmente com capacidade para atracação de embarcações, formando uma estrutura de proteção marítima do tipo convergente (ALFREDINI; ARASAKI, 2009), mostrada na Figura 1.

A bacia do porto de abrigo, com uma área molhada de aproximadamente $233.000 \mathrm{~m}^{2}$ e uma embocadura com cerca de $150 \mathrm{~m}$ de largura, é uma zona de fundos tipicamente arenosos (SILVA, 2002), variando a sua profundidade entre $-1 \mathrm{~m}(\mathrm{ZH})$ e -10 $\mathrm{m}(\mathrm{ZH})$, situando-se a profundidade máxima junto à cabeça do molhe principal.

O contra molhe possui uma extensão de cerca de $540 \mathrm{~m}$, tendo o molhe principal cerca de $980 \mathrm{~m}$ de comprimento, distribuídos em dois troços retos, nas direções $\mathrm{N}-\mathrm{S}$ e $\mathrm{N} 80^{\circ} \mathrm{E}$, existindo entre estes uma concordância em curva.

O troço inicial do molhe, com orientação $\mathrm{N}-\mathrm{S}$, perpendicular à linha da costa, apresenta na sua parte interior um talude com um declive de 3:2, constituído por um enrocamento de blocos de rocha com pesos entre $5 \mathrm{kN}$ e $20 \mathrm{kN}$, seguido de um filtro de rochas com pesos superiores a 0,2 kN e de um núcleo de enrocamento de todo o tamanho (ToT).

O troço terminal do molhe, com uma orientação $\mathrm{N} 80^{\circ} \mathrm{E}$, foi concebido para a atracação de navios, sendo o cais de acostagem uma estrutura do tipo gravítico, constituída por blocos de betão, com aproximadamente $300 \mathrm{~m}$ de extensão. A largura da superestrutura é de cerca de $18 \mathrm{~m}$, dispondo a mesma, na sua parte exterior, de um muro defletor, seguido de um manto protetor de blocos de betão, do tipo tetrápode, de 10 kN e 16 kN. O perfil tipo deste troço do molhe é indicado na Figura 2.

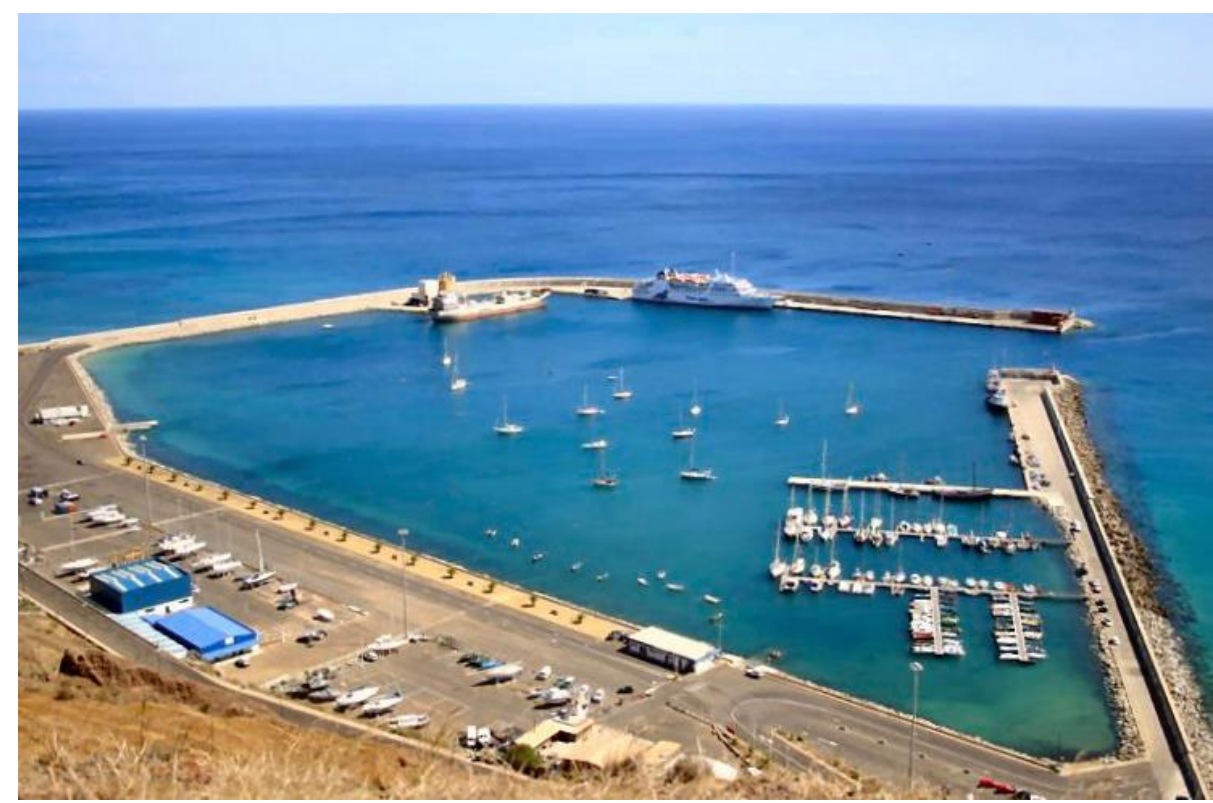

FIGURA 1: Vista geral do porto de abrigo antes das obras de reabilitação.

FONTE: Foto de Manuel Barcelos (2006) - Disponível em: http://olhares.sapo.pt/porto-de-abrigo-foto662895.html. 


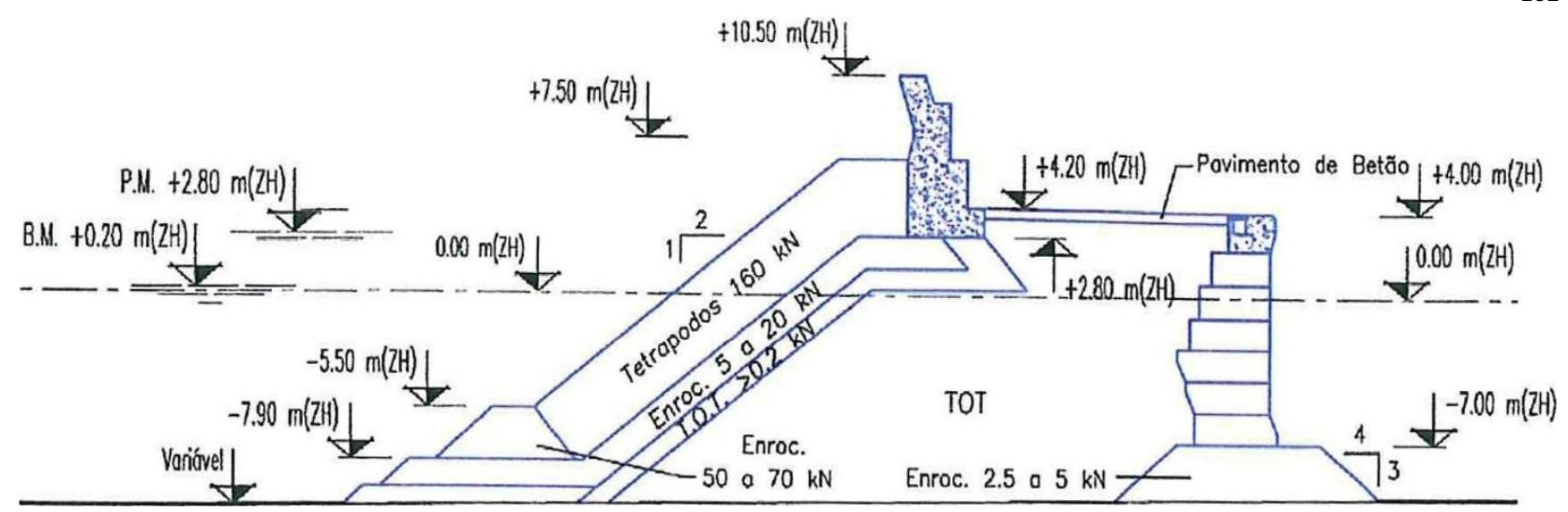

FIGURA 2: Perfil tipo do troço do molhe principal com orientação N80 ${ }^{\circ}$.

FONTE: WW (2006).

O contra molhe do porto de abrigo, que aparece à direita na Figura 1, é constituído por dois troços retos adjacentes. $O$ troço mais largo, com cerca de $220 \mathrm{~m}$ de extensão, situado na sua parte terminal, é constituído por blocos de betão assentes sobre um prisma de enrocamento protegido externamente por tetrápodes, formando uma estrutura de acostagem de paramento fechado (ALFREDINI; ARASAKI, 2009).

No troço inicial, onde está implantada uma marina de recreio, o talude interior do contra molhe é formado por enrocamento, sendo o talude externo composto por tetrápodes numa extensão de cerca de $110 \mathrm{~m}$. Na parte restante deste troço, mais próxima à linha da costa, a proteção exterior do molhe é constituída por um talude de enrocamento.

\section{INSPEÇÃO E AVALIAÇÃO ESTRUTURAL}

\subsection{TRABALHOS DE INSPEÇÃO E ESTUDOS PRELIMINARES}

Os trabalhos de reparação e reabilitação de obras marítimas e estruturas portuárias são normalmente antecedidos por inspeções detalhadas e pela avaliação da capacidade de carga da estrutura em questão (TSINKER, 2004).

Para a preparação das obras de reabilitação do porto de abrigo, foram realizadas as indispensáveis medições da profundidade e do relevo do fundo do mar na costa sueste da Ilha do Porto Santo, verificando-se declives pouco acentuados até a cota $-50 \mathrm{~m}(\mathrm{ZH})$, estando o fundo marinho coberto por areias com granulometria média a fina (WW, 2005).

Para além da consulta do Plano e Pormenor do Porto da Carta Náutica no 36401 - Illha do Porto Santo, do Instituto Hidrográfico português, foram realizados levantamentos detalhados no ano de 2005 (WW, 2005), nomeadamente:

(1) Levantamento hidrográfico no exterior do molhe do porto de abrigo, ao longo de uma faixa com cerca de $50 \mathrm{~m}$ de largura;

(2) Levantamento do manto do molhe de proteção com sonar de varrimento lateral;

(3) Inspeção à parte imersa do molhe e do manto, com registo vídeo, efetuada por equipa de mergulhadores;

(4) Inspeção visual do molhe principal do porto, com registo fotográfico da parte emersa;

(5) Levantamento topográfico da superestrutura e da parte emersa do manto resistente.

Dada a inexistência de medições in situ regulares de marés e correntes nas proximidades da Ilha do Porto Santo, foram utilizados dados de maré respeitantes ao porto do Funchal, na Ilha da Madeira, referentes a 2005, disponibilizados pelo Instituto Hidrográfico.

No entanto, determinou-se previamente a relação entre as amplitudes de maré observadas nos dois portos, com base em registos maregráficos 
obtidos em 1994, sendo esta de cerca de 1,06, tendo sido ainda considerado um aumento das cotas de 0,1 m, em decorrência da variação do nível do mar.

Os seguintes valores foram utilizados:

(1) Nível médio: $+1,4 \mathrm{~m}$ (ZH);

(2) Baixa-mar mínima: $+0,2 \mathrm{~m}(\mathrm{ZH})$;

(3) Preia-mar máxima: $+2,8 \mathrm{~m}(\mathrm{ZH})$.

No dimensionamento das obras de proteção, as correntes oceânicas e de maré foram consideradas insignificantes na baía do porto do Porto Santo (WW, 2006).

Face à inexistência, à época, de medições in situ de ondas no Porto Santo, as condições de agitação marítima foram determinadas sobre a batimétrica $-10 \mathrm{~m}(\mathrm{ZH})$ e ao longo de um segmento de reta situado à frente da obra a reparar com recurso a um modelo espectral de propagação de ondas (LIN, 2008). Foram também tidos em conta os dados de agitação marítima recolhidos desde 1989 pela boia ondógrafo fundeada ao largo do porto do Funchal, na costa sul da Ilha da Madeira.

Na caracterização da agitação marítima, foi utilizado o módulo NSW (Nearshore Spectral Wind-Wave Module) do modelo MIKE 21 (WW, 2006), desenvolvido pelo Danish Hydraulic Institute (DHI) com base na abordagem proposta por Holthuijsen et al. (1989), que simula o crescimento, propagação e decaimento de ondas de curto período em zonas costeiras e águas rasas, tendo em consideração diversos parâmetros, incluindo o vento, o atrito com o fundo e a rebentação das ondas, responsáveis pela dissipação da sua energia, bem como o efeito da refração e do empolamento provocados pela variação de profundidade.

Os valores extremos da altura significativa das ondas verificados na costa sul da Ilha da Madeira, medidos pela boia ondógrafo do Funchal, serviram de ponto de partida para o estudo da estabilidade do manto resistente do molhe.

Para um período de retorno de 50 anos, foram adotados os valores máximos de altura de onda significativa de 7,1 m e 6,8 $\mathrm{m}$, ao largo, para os rumos $225^{\circ} \mathrm{SW}$ e $180^{\circ} \mathrm{S}$, respetivamente (SOUSA, 2011), sendo destes valores extraídas as alturas significativas de onda no alinhamento do molhe principal do porto do Porto Santo, tendo o dimensionamento do manto resistente do molhe sido efetuado com base numa altura significativa máxima das ondas de 7,4 m na cota $-10 \mathrm{~m}(\mathrm{ZH})$.

\subsection{PRINCIPAIS ANOMALIAS E PATOLOGIAS OBSERVADAS}

A cuidadosa avaliação da estrutura existente, objetivando identificar anomalias e patologias estruturais e caracterizar e diagnosticar as suas causas, é a etapa mais importante no planeamento dos trabalhos de reparação e reabilitação estrutural (THORESEN, 2014).

Nas inspeções e levantamentos realizados nas partes emersa e submersa dos molhes de proteção do porto, diversas anomalias e patologias estruturais e não estruturais foram detetadas.

No troço do molhe principal com orientação $\mathrm{N} 80^{\circ} \mathrm{E}$, constataram-se várias fissuras longitudinais no pavimento da superestrutura, sendo evidente o estado de degradação de algumas zonas junto ao cais de acostagem (Figura 3). Observou-se, ainda, uma acentuada deterioração do seu manto de proteção, assim como uma pequena inclinação do muro de cortina no sentido do mar.

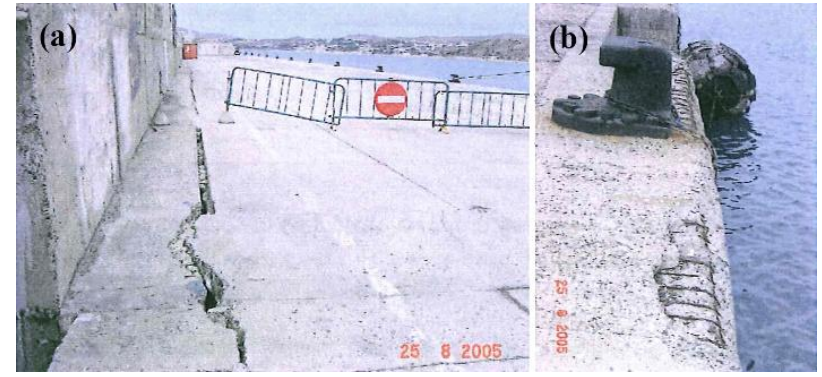

FIGURA 3: [a] Fissuras e [b] degradação na superestrutura. FONTE: WW (2006).

Tais situações deveram-se, fundamentalmente, ao assentamento da estrutura, uma vez que as suas fundações perderam parte do enrocamento do núcleo e dos filtros devido à degradação de muitos dos blocos de betão que constituíam o manto de tetrápodes, bem como à deslocação de outros da sua posição original, comprometendo assim a proteção da estrutura, ao deixar zonas com uma só camada de tetrápodes ou 
mesmo sem nenhuma proteção contra a ação da agitação marítima.

No troço inicial do molhe, com orientação $\mathrm{N}-\mathrm{S}$, muitos dos tetrápodes encontravam-se, igualmente, partidos ou afastados da sua posição original. Apesar dos danos verificados na estrutura serem menos significativos, em comparação com aqueles identificados no outro troço, esses poderiam, com o tempo, comprometer a proteção dos enrocamentos do filtro e do núcleo, deixando assim a estrutura suscetível a novos assentamentos.

No contra molhe do porto de abrigo foram também encontrados muitos tetrápodes partidos ou deslocados, porém a superestrutura não apresentava nenhum dano significativo.

\section{SOLUÇÃO DE REABILITAÇÃO ADOTADA}

Após a inspeção e diagnóstico dos problemas existentes nos molhes do porto de abrigo da Ilha do Porto Santo, seguiu-se a confrontação de todas as soluções possíveis, objetivando escolher aquela mais viável a todos os níveis e com o menor impacto ambiental.

Tendo por base os dados que haviam sido previamente recolhidos e interpolados, os cálculos efetuados de acordo com a formulação de Hudson (PITA, 1986; TAVEIRA-PINTO; NEVES, 2003) indicaram que, para a adequada proteção do manto, deveria ser este composto por duas camadas de elementos (blocos de betão do tipo Antifer) com um peso superior a $280 \mathrm{kN}$, devendo os enrocamentos adjacentes ter pesos entre os 20 kN e os $30 \mathrm{kN}$.

As Tabelas 1 e 2 apresentam as características dos elementos projetados para o manto protetor do molhe principal do porto de abrigo.

\section{TABELA 1: Características do manto de blocos Antifer.}

Cálculo do peso dos blocos

\begin{tabular}{ccc}
\hline & Altura de onda [m] & 7,4 \\
& Inclinação do talude [-] & 2 \\
Pados para cálculo & Período médio da onda [s] & 16 \\
(danos de 0 a 5\%) & Peso específico [kN/m²] & 25 \\
& Número de camadas [-] & 2 \\
& Coeficiente de estabilidade [-] & 7 \\
Peso calculado & Coeficiente de forma [-] & 1,05 \\
Peso adotado & (Fórmula de Hudson) [kN] & 280 \\
Espessura do manto & {$[\mathrm{kN}]$} & 300 \\
\hline
\end{tabular}

TABELA 2: Características do enrocamento.

Cálculo do peso do enrocamento

\begin{tabular}{ccc}
\hline Dados para cálculo & Peso específico $\left[\mathrm{kN} / \mathrm{m}^{2}\right]$ & 26 \\
& Coeficiente de forma $[-]$ & 1,15 \\
Peso estimado & {$[\mathrm{kN}]$} & 30 \\
Peso adotado & {$[\mathrm{kN}]$} & 25 \\
Espessura do filtro & {$[\mathrm{m}]$} & 2,3 \\
\hline
\end{tabular}


É importante referir que a fórmula de Hudson, que tem como principal vantagem a sua simplicidade, tem sido largamente utilizada no dimensionamento de proteções contra a ação das ondas, embora possua algumas limitações, devido ao facto de não ter em conta as características do manto resistente nem considerar alguns parâmetros hidrodinâmicos tidos como relevantes para a sua estabilidade (TAVEIRA-PINTO; NEVES, 2003; CIRIA et al., 2007).

A solução a construir ficou então definida pela reabilitação do molhe principal e a reparação do manto, até então constituído por blocos de betão do tipo tetrápode com $160 \mathrm{kN}$, substituindoos por blocos cúbicos Antifer com 300 kN. Esta substituição do tipo de blocos nas zonas de maior intensidade da dinâmica marítima objetivou obter um manto mais rígido, estável e duradouro, tornando-se assim mais robusto e menos propício a deslocamentos, diminuindo com isto a probabilidade de rutura dos seus elementos constituintes.

Como as inspeções e levantamentos efetuados revelaram a existência de diversos tetrápodes partidos, e tendo em conta que na llha do Porto Santo é muito difícil dispor de rochas rígidas e em grandes volumes, esses blocos de betão foram "reciclados" - isto é, reutilizados de acordo com as características definidas em projeto - juntamente com o enrocamento antes existente, formando com isto um filtro com um mínimo de 2,3 $\mathrm{m}$ de espessura, constituído por uma camada de enrocamento de $20 \mathrm{kN}$ a $30 \mathrm{kN}$.

Sobre esse enrocamento, definiu-se a colocação de blocos Antifer de $300 \mathrm{kN}$, cada um com um volume de betão de $12,5 \mathrm{~m}^{3}$, formando duas camadas com inclinação de 2:1, sendo a berma igualmente constituída pelo mesmo tipo de blocos.

A diminuição do ângulo de montagem dos blocos constituintes do manto para cerca de $26^{\circ}$ permitiu um avanço da proteção do molhe principal para o mar de cerca de 12 a $15 \mathrm{~m}$, permitindo com isto uma ampliação da área de rebentação das ondas (SETH, 2016).

A cabeça do molhe, por se tratar de uma zona crítica da estrutura marítima, foi também protegida por meio da substituição dos tetrápodes originais por blocos cúbicos Antifer, que apresentam um melhor comportamento hidráulico (FABIÃO, 2012).

Pelo facto da llha do Porto Santo situar-se numa zona oceânica em que a agitação marítima, embora significativa, não é considerada excessivamente elevada, a cabeça do molhe não foi protegida de maneira uniforme, sempre à mesma cota. Se não fosse este o caso, por uma questão de segurança, deveria ter sido realizado um estudo em modelo físico reduzido, de modo a obter melhor informação quantitativa sobre a estabilidade e poder identificar a zona mais crítica do manto, possibilitando assim a escolha da melhor geometria para a cabeça da estrutura (FABIÃO, 2012).

No entanto, o molhe do Porto do Porto Santo não possui uma estrutura completamente linear, pois apresenta um pequeno aumento do comprimento transversal na cabeça do molhe, como é possível observar na Figura 4.

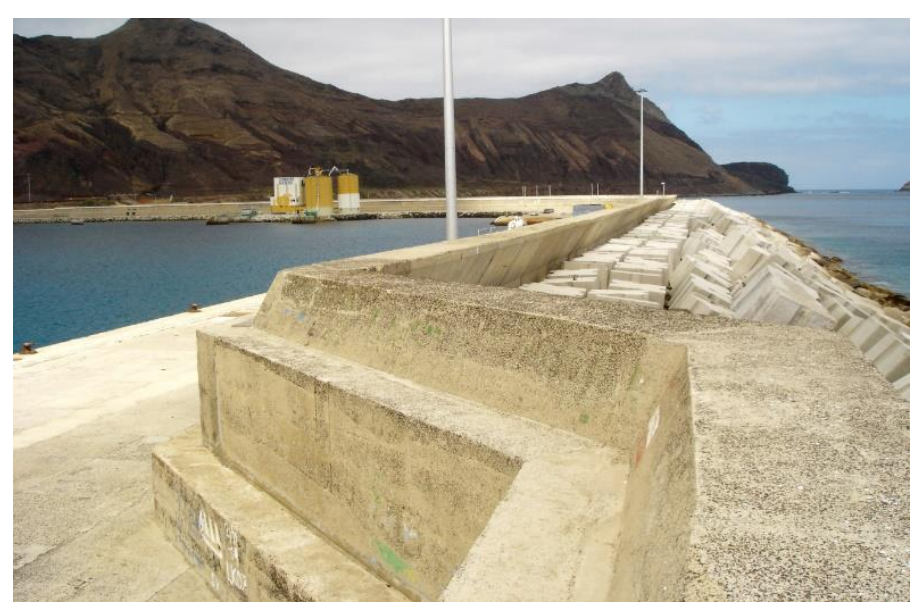

FIGURA 4: Aumento da secção na zona da cabeça do molhe. FONTE: Autoria própria - Nuno Sousa (2011) 
Na maior parte das situações, a zona mais crítica da cabeça da estrutura pode ser melhor protegida por meio do aumento do diâmetro da secção frontal ou, então, pelo seu prolongamento no sentido preponderante de incidência das ondas, soluções estas que proporcionam uma diminuição da altura das ondas por difração, reduzindo assim o efeito da sua ação sobre a estrutura de proteção (CERC, 1984).

A solução adotada, de colocação dos cubos Antifer ao longo do manto, com a configuração exposta na Figura 5, contribuiu para a estabilidade do muro de cortina e possibilitou a obtenção de um filtro poroso, porém, ao mesmo tempo, mais capaz de impedir o escape de enrocamento do núcleo do que a solução préexistente.

Em relação ao troço $\mathrm{N}-\mathrm{S}$ do molhe e ao contra molhe, zonas menos expostas à ação da agitação marítima, como não se justificava a substituição do tipo original de blocos, procedeu-se apenas à sua reorganização e à substituição dos blocos partidos, obtendo-se desta forma um perfil estável com os tetrápodes de 100 kN.

Existem duas configurações possíveis, côncava ou convexa, para os molhes que apresentam uma mudança acentuada de direção ao longo de sua extensão (CERC, 1984), sendo o molhe principal do porto do Porto Santo do tipo convexo.

Em função da configuração do molhe, foram determinados o tipo e o peso dos blocos, o seu posicionamento, bem como a espessura da camada de proteção, uma vez que os blocos situados nas esquinas do tipo convexo estão mais expostos à dinâmica marítima, enquanto os blocos a eles lateralmente vizinhos encontram-se sujeitos a menos esforços.

Em consequência disso, a fronteira entre os tetrápodes e os blocos Antifer, de maior peso, ficou situada próximo ao final do troço N-S, como mostra a Figura 6, o que não seria possível caso se tratasse de uma zona mais fustigada pela agitação marítima, situação em que seria prudente que a fronteira se situasse mais junto à costa.

Antes das obras de reparação, a superestrutura do molhe apresentava algumas patologias, incluindo fissuras longitudinais e degradação junto à borda do cais acostável (Figura 3), tendo-se procedido à sua reparação e selagem com betão C35/45 e com um ligante epoxídico estrutural, capaz de assegurar a aderência do novo betão ao antigo.

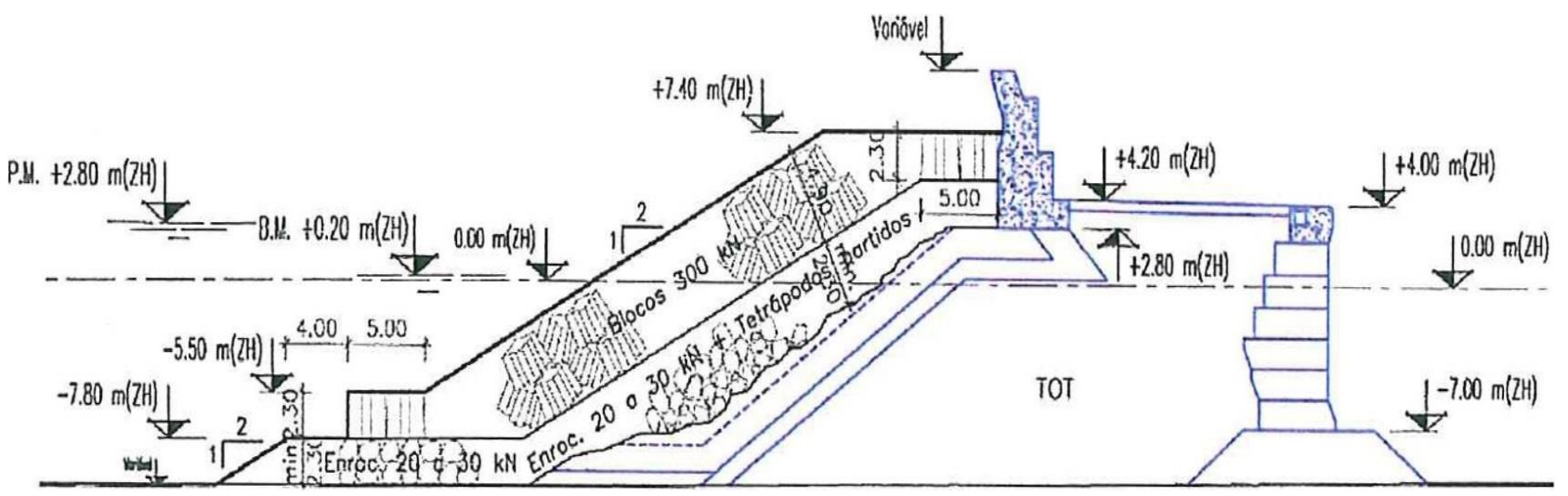

FIGURA 5: Perfil de reconstrução do molhe.

FONTE: WW (2006) 


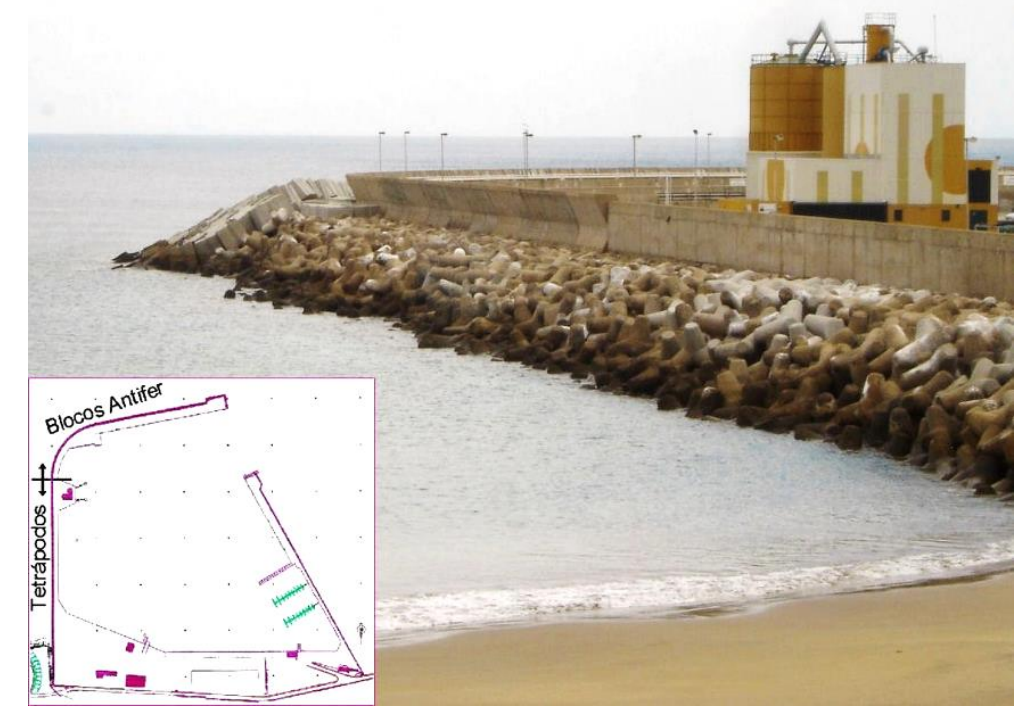

FIGURA 6: Tipo e localização dos blocos de betão utilizados no manto para a reabilitação do molhe. FONTE: FONTE: Autoria própria - Nuno Sousa (2011).

Os tetrápodes já existentes e em boas condições foram retirados do molhe principal e recolocados no contra molhe, tendo os demais blocos necessários para a proteção do contra molhe sido fabricados segundo o mesmo modelo.

Para além dos trabalhos marítimos antes mencionados, que abrangeram $90 \%$ da empreitada (SETH, 2016), o projeto de execução envolveu alterações e outras construções na zona de acesso ao porto, como, por exemplo, obras de drenagem, muros de contenção e instalações elétricas, que, não sendo o foco de interesse deste trabalho, não serão aqui discutidas.

\section{TRABALHOS DE REPARAÇÃO REABILITAÇÃO}

Tratando-se de uma obra de engenharia com uma dimensão razoável, orçada em 19 milhões de euros e com uma duração de 24 meses, tendo como promotor a APRAM - Administração dos Portos da Região Autónoma da Madeira, S.A., foi estabelecido um consórcio de empresas para a sua execução, constituído designadamente pela ETERMAR - Engenharia e Construção S.A., SOMAGUE - Engenharia S.A., Seth - Sociedade de Empreitadas e Trabalhos Hidráulicos, S.A.e
Construtora do Tâmega S.A., tendo o projeto sido da responsabilidade da WW - Consultores de Hidráulica e Obras Marítimas, S.A.

A obra iniciou-se em janeiro de 2007, tendo os primeiros dias de trabalho sido dedicados à consignação e à criação de um rigoroso plano de segurança e saúde, capaz de evitar, tanto quanto possível, qualquer risco para os intervenientes diretos na obra, bem como para os demais utilizadores da via marítima, uma vez que o porto continuou em funcionamento durante os trabalhos, embora com alguns constrangimentos.

A escolha do local para a instalação do estaleiro e a sua construção, envolvendo a mobilização do equipamento necessário, foram primeiramente executadas, ocorrendo em seguida a montagem das instalações, logo após a finalização do plano de segurança e saúde.

Após essa primeira etapa, seguiram-se trabalhos preparatórios, envolvendo em especial a execução de levantamentos topo-hidrográficos e inspeções submarinas, objetivando obter dados adicionais que permitissem confirmar aqueles que haviam sido recolhidos no ano de 2005 ou indicar a existência de eventuais alterações, de modo a que as mesmas pudessem ser retificadas e tidas em conta aquando da execução da obra. 
A atividade seguinte foi a pré-fabricação dos blocos Antifer e dos tetrápodes, que apresentou um rendimento variável entre os dez e os 12 blocos por dia, não tendo sido o ritmo de produção de blocos mais elevado devido às limitações da produção diária de betão na llha do Porto Santo.

Para essa atividade, primeiramente o terreno escolhido para a colocação dos moldes foi aplainado e coberto com areia, com o auxílio de uma retroescavadora, tendo sido os moldes em seguida colocados de forma ordenada, obtendo-se assim um melhor aproveitamento do espaço e uma maior facilidade de manuseio dos equipamentos.

A betonagem foi feita de forma direta pelas autobetoneiras, que, por meio de uma rampa metálica movida de molde para molde por uma grua móvel, conseguiam chegar ao topo dos moldes, possibilitando com isto uma betonagem eficiente. Os moldes utilizados foram também adaptados, de forma a criar uma guarda para a proteção dos trabalhadores e estabelecer uma ligação de passagem entre os mesmos (Figura 7).

Após a realização da betonagem, os espaços vazios remanescentes foram eliminados com a utilização de um vibrador de betão alimentado por um gerador. A descofragem dos moldes metálicos (Figura 8) foi efetuada passado algum tempo, após o betão já apresentar uma determinada consistência.
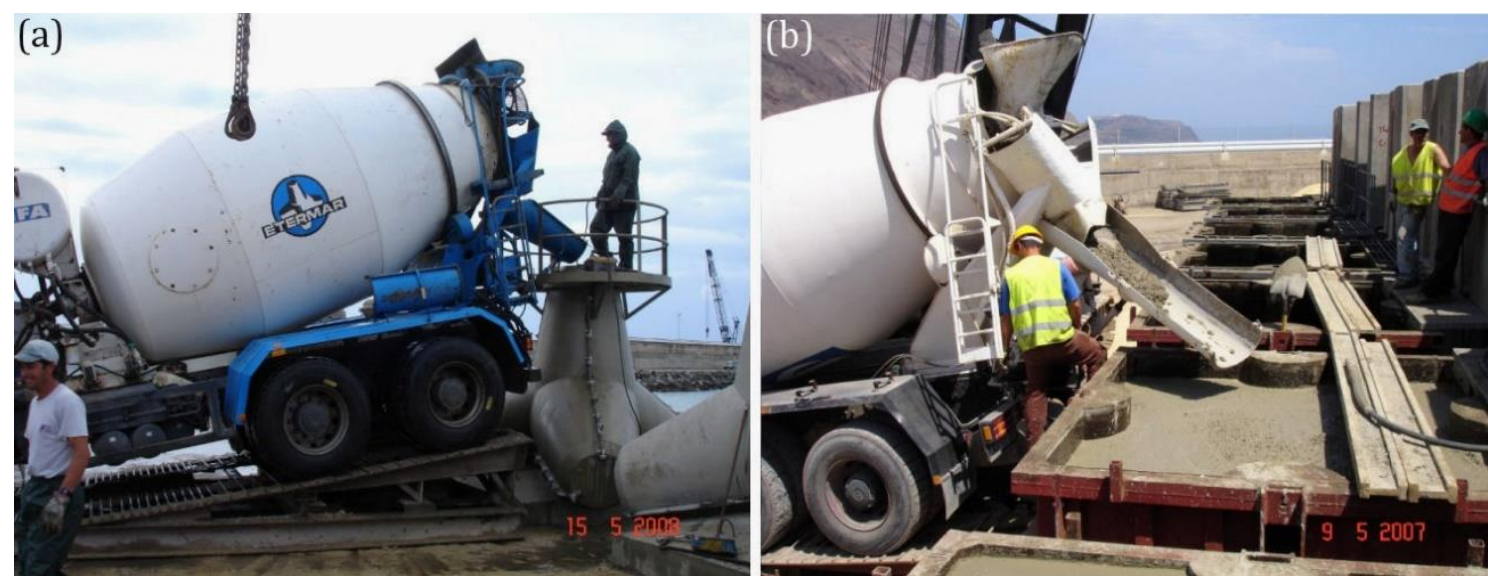

FIGURA 7: Betonagem [a] dos tetrápodes e [b] dos blocos Antifer usados no manto do molhe. FONTE: ETERMAR - Foto cedida pela Delegação do Funchal, 2011.

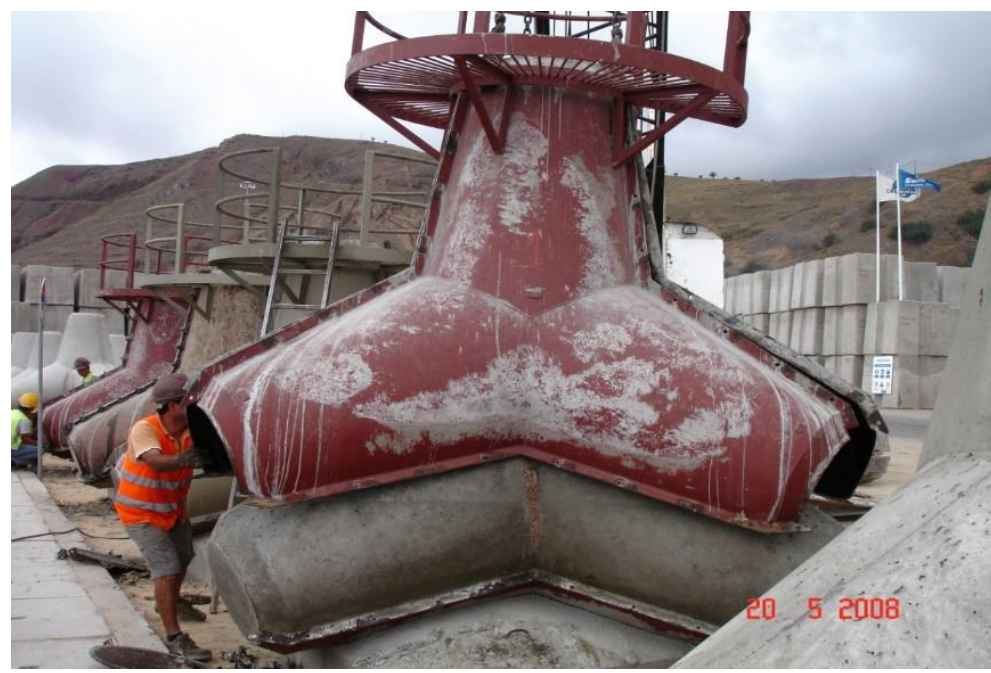

FIGURA 8: Desmoldagem dos tetrápodes.

FONTE: ETERMAR - Foto cedida pela Delegação do Funchal, 2011. 
O passo seguinte foi a cura do betão, garantida pela rega abundante dos blocos com água bombeada de um poço de armazenamento construído nas proximidades, evitando, desta forma, a sua desidratação descontrolada.

Quatro a seis dias após a betonagem, quando os blocos já possuíam alguma resistência mecânica, estes eram transportados da zona de fabrico para a zona de stock, onde acabariam por atingir a resistência final especificada no projeto.

Este ciclo de pré-fabricação de blocos decorreu ao longo de cerca de um ano, período no qual foram realizadas diversas atividades, sendo uma das mais importantes a montagem de um pórtico com uma grua de grande capacidade para a remoção e colocação dos blocos de betão destinados à constituição do manto de proteção do molhe principal.

A grua amovível utilizada, TWH Manitowoc 4100 Ringer, foi adaptada para se mover sobre dois carris, apoiados um sobre o pavimento do porto e outro sobre o muro de cortina (Figura 9), cuja construção, devido aos assentamentos e a algumas imperfeições verificadas no molhe, bem como às características próprias do equipamento, implicou um trabalho demorado e minucioso, apoiado em métodos topográficos.

A referida grua, com um peso total (grua, contrapesos e lança) de $400 \mathrm{t}$, tinha capacidade para colocação dos blocos de betão de $300 \mathrm{kN}$ a $50 \mathrm{~m}$, possuindo a lança utilizada um comprimento de $61 \mathrm{~m}$ e uma secção de $3 \times 2 \mathrm{~m}$ (SETH, 2016).

À medida que os trabalhos foram decorrendo, a execução dos carris realizou-se sempre de forma antecipada, de modo a permitir que a grua pudesse se deslocar acompanhando o avanço da frente de colocação dos blocos.

Os carris metálicos foram chumbados e aparafusados no muro de cortina sobre um perfil em $L$ invertido e apoiados no pavimento do porto sobre uma viga em betão armado construída especificamente para o efeito.

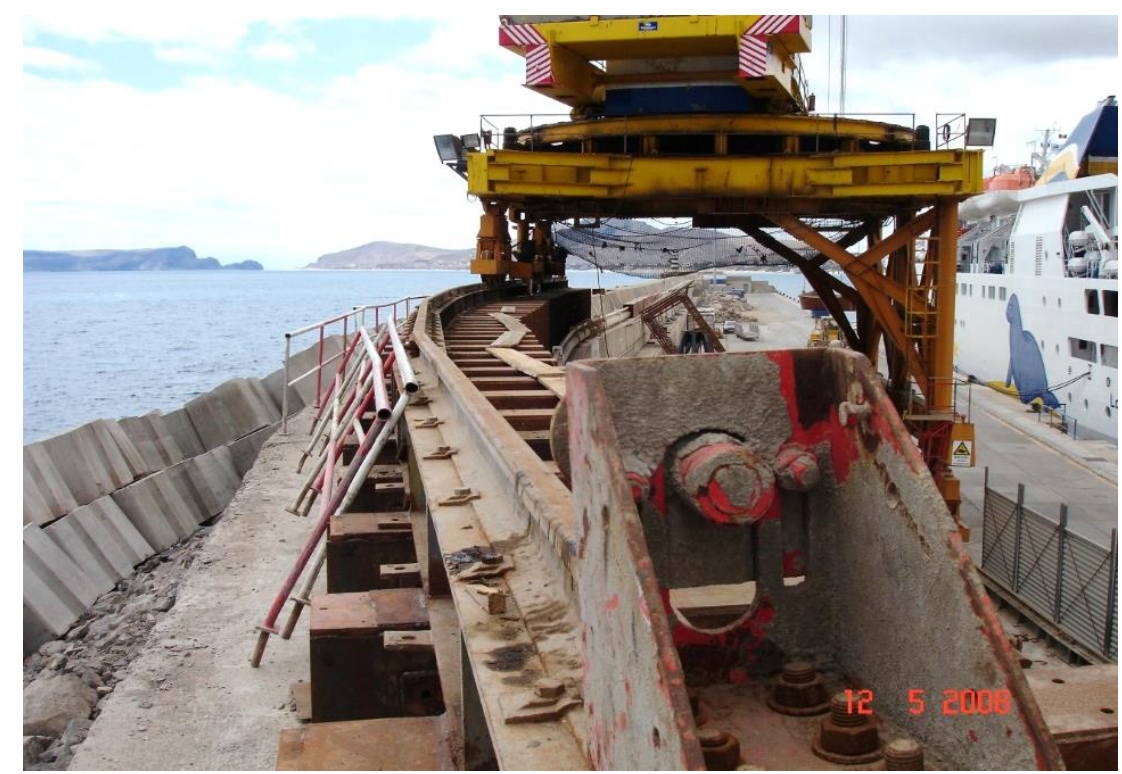

FIGURA 9: Base da grua para movimentação dos blocos constituintes do manto do molhe principal. FONTE: ETERMAR - Foto cedida pela Delegação do Funchal, 2011. 
A opção pelo apoio da grua sobre um pórtico deveu-se ao maior alcance que esta poderia atingir e, consequentemente, sua melhor capacidade para a colocação dos blocos de betão na posição indicada no projeto.

Outra solução seria a colocação do material no manto através de meios marítimos como, por exemplo, batelões, pontões ou gruas flutuantes -, havendo diversos meios para atingir tal fim, embora tenham estes custos de manutenção, tempos de execução e formas de aplicação diferentes, o que realça a importância da escolha acertada dos equipamentos para que o progresso das obras marítimas possa decorrer sem que sucedam falhas de execução, que implicam, inevitavelmente, derrapagens orçamentais.

No manto do molhe principal, primeiramente foram retirados pela grua os blocos de betão pré-existentes, do tipo tetrápode, tendo sido estes transportados para a zona de armazenamento do estaleiro, onde foram inspecionados e, conforme o seu estado de conservação, decidido o seu destino.

Os tetrápodes que se mostraram capazes de desempenhar a função a que se destinam, foram armazenados para, posteriormente, serem recolocados no manto resistente do molhe, tendo sido os demais blocos encaminhados para outra zona do estaleiro, onde foram quebrados, dando origem a blocos mais pequenos a serem utilizados no enrocamento do manto protetor.

A seguir, procedeu-se a trabalhos de dragagem, objetivando o nivelamento e a preparação da zona de assentamento dos blocos, tendo-se verificado um aumento dos volumes com a aproximação à costa, tal como indicado nos estudos prévios de batimetria.

Após as dragagens, realizou-se o reperfilamento do enrocamento com os tetrápodes partidos e com rochas basálticas, rochas estas mais resistentes que as de natureza sedimentar previamente existentes, uma vez que muitas destas rochas encontravam-se quebradas ou fragmentadas, deixando com isto de cumprir com as características estipuladas.

O depósito de enrocamento foi realizado pela grua por meio de uma caixa metálica, como mostrado na Figura 10, tendo sido posteriormente nivelado e corrigido com recurso a uma escavadora hidráulica Caterpillar 320.

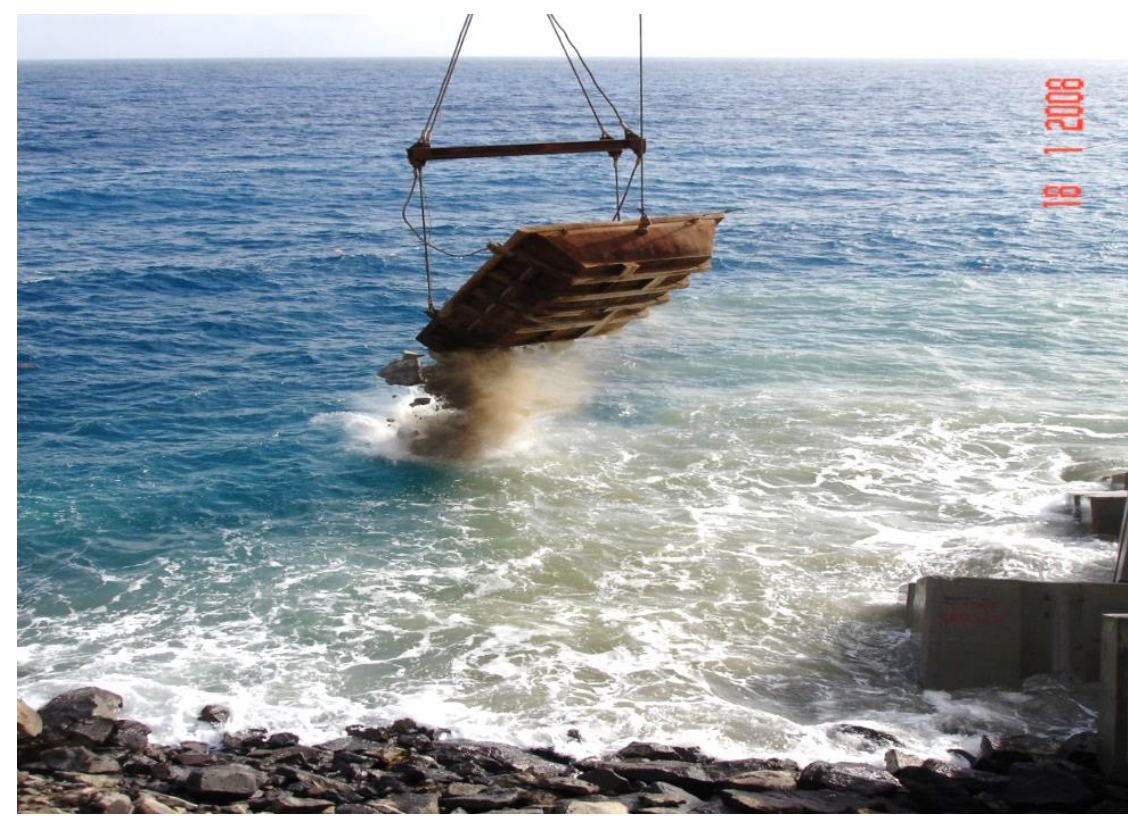

FIGURA 10: Deposição de enrocamento com auxílio da grua. FONTE: ETERMAR - Foto cedida pela Delegação do Funchal, 2011. 
Para concluir o manto de proteção da estrutura de enrocamento do molhe, foram depositados pela grua os dois tipos de blocos, consoante a zona definida no projeto, sendo para tal utilizada, no caso dos blocos Antifer, uma garra mecânica, conforme mostrado na Figura 11.

De notar que em nenhum dos tipos de blocos empregues foram acoplados os usuais ganchos metálicos, frequentemente utilizados para a sua movimentação e manuseio, a fim de evitar que o contacto destes com a água do mar pudesse levar à corrosão do aço e à consequente aceleração do processo de deterioração do betão.

Nas zonas em que os blocos ficaram submersos, a orientação para o correto posicionamento dos mesmos foi assegurada por dois mergulhadores, com a utilização de boias, sendo estes auxiliados por um operador a bordo de uma lancha, responsável pela ponte de comunicação com o operador da grua (Figura 12). Outra possibilidade para a correta colocação dos blocos, de acordo com as coordenadas que constam no projeto, seria o acoplamento à grua de um GPS com correção diferencial, caso em que se tornaria desnecessário o auxílio da lancha.

Finalizado o primeiro troço, com cerca de $30 \mathrm{~m}$, foi repetido todo o processo, desde o alinhamento dos carris até à colocação dos blocos de betão, tendo assim a reabilitação do molhe ocorrido de forma faseada e não por atividade.
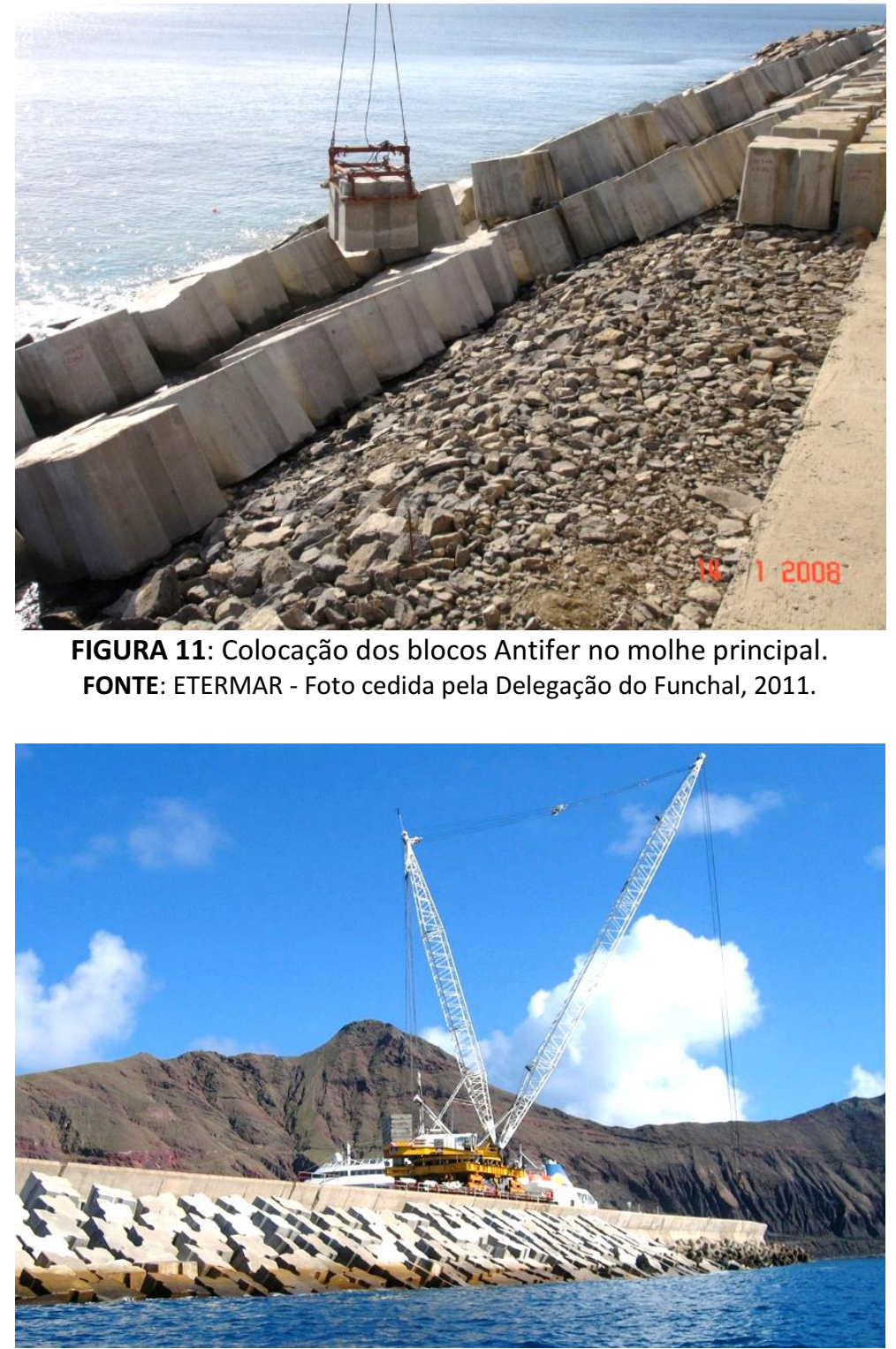

FIGURA 12: Grua usada na colocação dos blocos Antifer abaixo da linha de água.

FONTE: TSM, 2017. Extraída de: https://www.tsmcommercialdivers.com/images/portfolio/porto-santo-reparacao.jpg. 
A reparação do contra molhe, incluindo a substituição dos tetrápodes e as demais atividades envolvidas, seguiu um procedimento semelhante ao adotado para o molhe principal, residindo a diferença essencialmente na não necessidade de trabalhos de dragagem e no equipamento empregue, tendo sido neste caso utilizada uma grua NCK Ajax, implicando menos trabalhos de topografia para a colocação dos carris.

Procederam-se, ainda, a demolições e remoções de material em algumas zonas danificadas do molhe principal que necessitavam de reparação da superestrutura, em decorrência de assentamentos ou desgastes provocados pela atracação de navios.

\section{MATERIAIS E RECURSOS UTILIZADOS}

\subsection{QUANTIDADES DE MATERIAIS EMPREGUES}

A reabilitação do porto de abrigo da llha do Porto Santo envolveu a utilização de muitos recursos materiais e humanos, tal como ocorre com a maior parte das obras marítimas.

Em relação aos blocos de betão constituintes do manto protetor, foram removidas e posteriormente recolocadas 1.502 unidades de tetrápodes de $100 \mathrm{kN}$, bem como fabricadas e colocadas outras 270 unidades do mesmo tipo, com o mesmo peso, num total de $1.130 \mathrm{~m}^{3}$ de betão.

No troço previsto para substituição do tipo de blocos, foram fabricadas e posteriormente colocadas 4.000 unidades de blocos cúbicos Antifer de 300 kN, num total de $50.875 \mathrm{~m}^{3}$ de betão.

A quantidade dos distintos tipos blocos de betão utilizados nas obras de reabilitação do porto de abrigo do Porto Santo encontra-se sumarizada na Tabela 3. No total, foram empregues cerca de $52.000 \mathrm{~m}^{3}$ de betão C35/45 (SETH, 2016).

Para a constituição das camadas de enrocamento, foram colocados $58.582 \mathrm{~m}^{3}$ de rochas basálticas, com pesos entre $20 \mathrm{kN}$ e $30 \mathrm{kN}$, e mais $2.550 \mathrm{~m}^{3}$ do mesmo tipo de rochas com pesos a variar entre 0,5 kN e 1,5 kN. A reabilitação do núcleo, em decorrência do escape de material, exigiu cerca de $1.540 \mathrm{~m}^{3}$ de material com peso inferior a 0,5 kN.

As quantidades de materiais empregues na constituição das camadas de enrocamento e do núcleo encontram-se sintetizadas na Tabela 4.

TABELA 3: Resumo das quantidades de blocos de betão utilizadas.

\begin{tabular}{ccc} 
Tipo de material & Unidades & $\mathbf{m}^{\mathbf{3}}$ \\
\hline Tetrápodes 100 kN (removidos) & 1.502 & 6.286 \\
Tetrápodes 100 kN (fabricados) & 270 & 1.130 \\
Antifer 300 kN (fabricados) & 4.000 & 50.875 \\
\hline Total & 5.772 & 58.291 \\
\hline
\end{tabular}

\section{TABELA 4: Resumo das quantidades de material constituinte do núcleo.}

\begin{tabular}{cc} 
Tipo de material & $\mathbf{m}^{\mathbf{3}}$ \\
\hline Enrocamento $(20 \mathrm{kN}-30 \mathrm{kN})$ & 58.582 \\
Enrocamento $(0,5 \mathrm{kN}-1,5 \mathrm{kN})$ & 2.550 \\
Enrocamento $(<0,5 \mathrm{kN})$ & 1.540 \\
\hline Total & 62.672 \\
\hline & FONTE: ETERMAR (2011).
\end{tabular}


Os materiais de enrocamento depositados no manto foram provenientes de uma exploração feita propositadamente para obra em questão. Apesar das formações sedimentares serem significativas na llha do Porto Santo (CARVALHO; BRANDÃO, 1991), a pedreira localizouse sobre um estrato de basalto, rocha muito dura, ideal para o enrocamento do molhe.

As dragagens realizadas envolveram um volume da ordem dos $25.000 \mathrm{~m}^{3}$ (SETH, 2016).

\subsection{MEIOS HUMANOS E EQUIPAMENTOS UTILIZADOS}

A obra foi dirigida permanentemente por dois engenheiros civis, responsáveis pelo controlo de produção, tendo como principal função assegurar que a preparação e execução da obra seguisse rigorosamente o projeto, bem como controlar os custos orçamentados, sendo ainda responsáveis por toda a logística envolvida, incluindo equipamentos, estaleiro da obra, recursos humanos e compras necessárias. Estes foram auxiliados no local por um encarregado geral e por um técnico de higiene e segurança.

A atividade de fabrico dos blocos em betão, do tipo Antifer e tetrápodes, envolveu diretamente 12 homens, quatro deles - dois pedreiros e dois serventes - diretamente envolvidos no processo de betonagem. Estes tinham por função garantir o posicionamento correto dos moldes e da rampa, de modo a proporcionar a betonagem direta, bem como acelerar a saída do betão quando este não apresentava a fluidez desejada.

No entanto, é de notar aqui que essa eventual menor fluidez proporcionou a obtenção de resistências superiores em menos tempo, permitindo com isto a descofragem precoce e, por conseguinte, um melhor rendimento na produção diária de blocos. Estes quatro trabalhadores tinham também por função reduzir os espaços vazios no interior do betão, com o emprego de um vibrador de betão alimentado por um gerador.

Após o betão adquirir alguma consistência, procedeu-se à descofragem dos blocos e à limpeza dos moldes com um óleo específico, sendo os blocos colocados nos camiões por meio de gruas móveis, existindo dois motoristas responsáveis pelo transporte dos blocos de betão para a zona de armazenamento, onde foram adequadamente hidratados com recurso a uma bomba de água.

No fabrico dos blocos, foram empregues 12 moldes para blocos de betão do tipo Antifer e quatro para tetrápodes, que foram betonados por uma frota composta por quatro autobetoneiras, implicando na existência de outros tantos motoristas para tal tarefa.

A movimentação dos moldes, da rampa e dos blocos produzidos (Figura 13) deveu-se ao permanente contributo de duas gruas móveis, manobradas por outros dois homens.

A fase da substituição dos enrocamentos e da colocação dos blocos no molhe principal envolveu a maior das máquinas mobilizadas para as obras de reabilitação do porto de abrigo do Porto Santo, a grua TWH Manitowoc 4100 Ringer, que foi minuciosamente norteada por uma equipa de topografia, constituída por um topógrafo e um ajudante de topógrafo, tendo a construção do pórtico para a grua sido executada por dois pedreiros e dois serventes. Todo o material removido, bem como o que foi substituído, foi movimentado com o auxílio da referida grua.

O material de enrocamento foi depositado na caixa metálica por uma pá carregadora operada por um manobrador, como mostrado na Figura 14, sendo em seguida movido pela grua. 


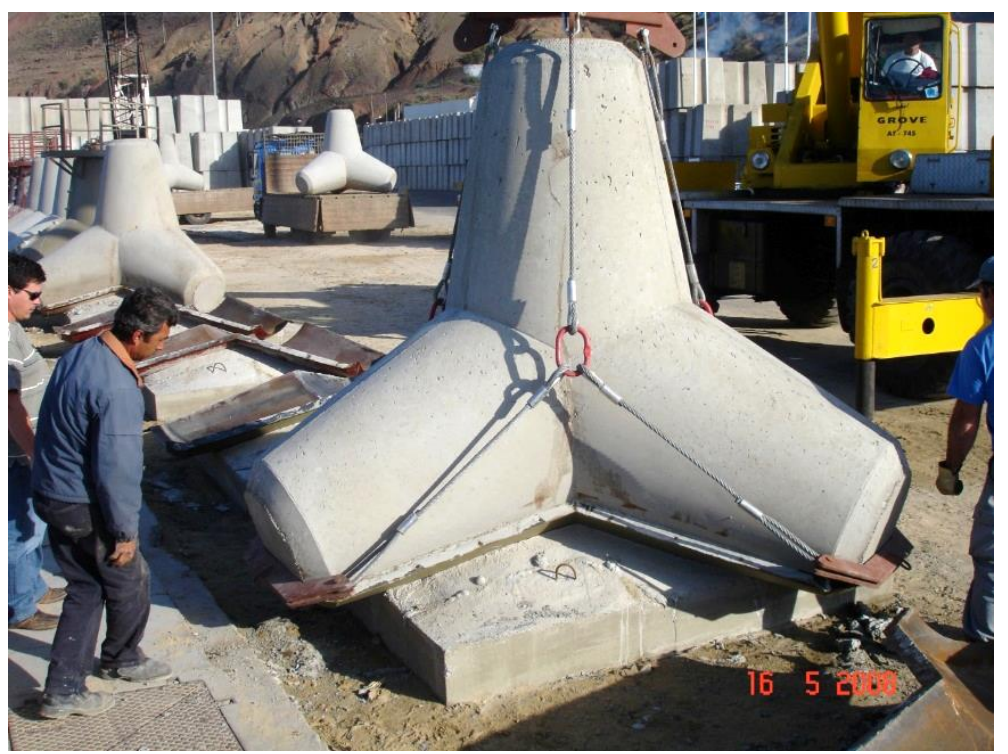

FIGURA 13: Movimentação dos tetrápodes visando o seu armazenamento.. FONTE: ETERMAR. Foto cedida pela Delegação do Funchal, 2011.

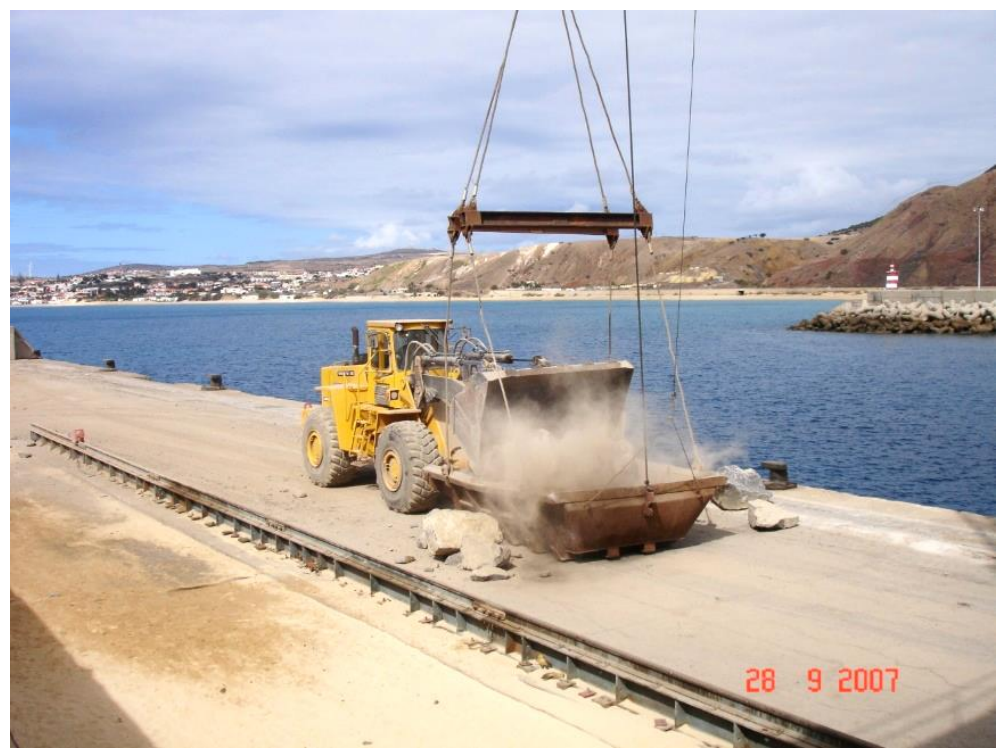

FIGURA 14: Pá carregadora a depositar rochas na caixa metálica. FONTE: ETERMAR. Foto cedida pela Delegação do Funchal, 2011.

Posteriormente, o enrocamento foi nivelado por uma escavadora de lagartas Caterpillar 320, igualmente operada por um manobrador.

A referida grua foi também utilizada na colocação dos blocos constituintes do novo manto resistente, blocos estes transportados até ao local por camiões.

No caso dos blocos de betão definidos para ficarem submersos, a orientação para o seu correto posicionamento, como antes referido, foi dada por dois mergulhadores, auxiliados por uma lancha conduzida pelo mesmo homem encarregue de estabelecer a ponte de comunicação com o operador da grua.
Na reparação do contra molhe do porto de abrigo, os meios humanos empregues e o equipamento mobilizado foram basicamente os mesmos, excetuando o emprego de uma grua NCK Ajax no lugar daquela utilizada na reparação do molhe principal.

Devido à escassez, na llha do Porto Santo, de material rochoso adequado às especificações do projeto a custos suportáveis, ouve a necessidade de encontrar uma solução económica e temporal que fosse viável.

Foram consideradas várias hipóteses, incluindo a colocação de um enrocamento constituído por uma rocha menos dura ou, ainda, o 
transporte de basalto da vizinha llha da Madeira, entre outras possíveis soluções, porém nenhuma se mostrou tão viável quanto a possibilidade de extração de rocha de um filão basáltico existente na própria llha do Porto Santo.

Inicialmente, o trabalho de extração de rocha foi executado com o auxílio de duas máquinas Caterpillar 325, uma com martelo hidráulico e outra com balde, capazes de partir e colocar o material rochoso extraído nos quatro camiões responsáveis pelo seu transporte até ao estaleiro montado na zona de terrapleno do porto de abrigo. No entanto, com o decorrer das obras de reabilitação, houve a necessidade do aumento da produção, o que implicou a mobilização de mais uma máquina Caterpillar 325, neste caso também com um martelo hidráulico.

Cabe por último referir que, após a execução desses trabalhos, houve o cuidado de se proceder ao aterro do local de extração, apresentado o terreno um perfil final idêntico àquele anterior à exploração.

\section{CONCLUSÕES E CONSIDERAÇÕES FINAIS}

Sendo este um trabalho que tem como principal objetivo descrever e analisar em detalhe os trabalhos de reabilitação do porto de abrigo da Ilha do Porto Santo, ficará restrito a essa obra o escopo das conclusões e considerações a seguir expostas.

Como pontos menos positivos, pode referir-se a ausência de medições in situ de ondas e a utilização de dados da boia ondógrafo fundeada ao largo do Porto do Funchal, na Ilha da Madeira, para a estimação, com o modelo numérico de propagação de ondas Mike 21 NSW, do estado do mar na zona do porto em estudo, que apresenta características distintas e está situada a cerca de 36 milhas náuticas de distância.

Além disso, a adoção do modelo simplificado de Hudson, com o emprego de tais dados aproximados, tornou o cálculo das características dos blocos de betão para a proteção da estrutura de acostagem um tanto menos confiável do que o dimensionamento que seria possível caso os dados utilizados com o referido modelo fossem resultantes de uma campanha prévia de medição de ondas in situ, sempre desejável, porém neste caso não executada.

Embora os modelos de simulação numérica de ondas, como o Mike 21 NSW, possam apresentar resultados bastante aceitáveis, nomeadamente para fins de dimensionamento de estruturas costeiras e oceânicas, os modelos físicos continuam a ser necessários para a calibração dos parâmetros e a validação dos resultados por eles fornecidos (MAl et al., 1999), sendo assim de referir a ausência de experiências em modelo reduzido aquando da execução do projeto das obras de reparação do porto de abrigo.

De acordo com a informação que foi possível recolher, parece também não ter havido o cuidado de realizar um exaustivo estudo do transporte litoral de sedimentos na costa sueste da Ilha do Porto Santo aquando da implantação dos molhes, na primeira metade da década de 1980, estudo este que seria indispensável para assegurar a minimização do impacto ambiental resultante da presença da estrutura de acostagem, fundamental por se tratar de uma ilha cujo desenvolvimento económico baseia-se, de forma muito significativa, na vertente turística, que está inevitavelmente relacionada com as condições do extenso areal da praia que a ela dá notoriedade.

Ademais, o projeto de estruturas marítimas e portuárias usualmente requer $\mathrm{o}$ conhecimento dos parâmetros das ondas incidentes, do nível do mar e das feições batimétricas. No entanto, as simulações numéricas realizadas não tiveram em conta o efeito das correntes costeiras e de maré no padrão de ondas no porto e na zona costeira adjacente, estudo que seria possível com o emprego, por exemplo, do módulo Mike 21 BW (Boussinesq Wave Module), embora o mesmo possa mostrar-se relativamente pouco sensível às variações da batimetria ( $\mathrm{OH}$ et al., 2009). 
Poderiam ter merecido uma melhor avaliação quanto à adequação da solução implementada - idealmente com recurso à modelação física e numérica - a localização da fronteira entre os dois diferentes tipos de blocos de betão utilizados, que foi determinada empiricamente, e a proteção da cabeça do molhe principal do porto, zona esta especialmente crítica para a estrutura.

De entre os pontos menos positivos relativos aos processos de construção adotados, pode referir-se primeiramente a não utilização de um GPS diferencial acoplado à grua que operou no molhe principal, o que tornaria dispensável a utilização da lancha de apoio e permitiria um posicionamento mais preciso dos blocos de betão.

Outra medida que poderia ter sido posta em prática com melhores resultados seria a colocação de uma manta geotêxtil (PILARCZYK, 2000) entre o núcleo e a camada adjacente do manto de proteção, o que poderia impedir a fuga do material mais fino do núcleo, minimizando o risco de indesejáveis assentamentos, como os verificados antes das obras de reabilitação.

Em vista das limitações na produção diária de betão na Ilha do Porto Santo, que constituíram uma forte condicionante em termos de prazo para a consecução da obra em função da grande demanda, uma solução mais adequada teria sido conjugá-la com uma produção própria, por meio da instalação e operação de uma pequena central de betão naquela ilha durante a execução das obras de reabilitação do porto de abrigo.

Por outro lado, quanto aos aspectos positivos, pode destacar-se, em primeiro lugar, a realização prévia de novos levantamentos topohidrográficos e inspeções submarinas, aquando da execução dos trabalhos de reabilitação, pois tais atualizações permitem a antecipação de eventuais imprevistos e a realização de reformulações de forma atempada, bem como a escolha de soluções alternativas mais viáveis e adequadas aos cenários encontrados.

A colocação direta do betão nos moldes dos blocos, com recurso a uma rampa metálica para
- nivelamento da autobetoneira com a parte superior dos mesmos, mostrou-se, igualmente, uma solução muito eficiente, por propiciar uma maior rapidez na betonagem, com menor mobilização de meios humanos, além de evitar a ocorrência de alterações nas propriedades do betão, que teriam lugar caso o processo demandasse mais tempo.

A opção pelo não acoplamento dos usuais ganchos metálicos nos dois tipos de blocos de betão produzidos, normalmente empregues na sua movimentação, mostrou ser também uma escolha acertada, por evitar a degradação dos blocos em decorrência da oxidação do aço de que são constituídos.

A criação do pórtico com os perfis metálicos em $L$, para apoio da grua utilizada na remoção e colocação dos elementos constituintes do manto no molhe principal, foi uma solução engenhosa e adequada, embora, como alternativa, pudesse ter sido considerada a colocação do material no manto com recurso a meios marítimos. No entanto, há que ter em conta que esta alternativa poderia ter sérias implicações em termos de operacionalidade dos meios a serem empregues e do próprio porto durante os trabalhos de reabilitação.

O emprego de uma grua de menor porte na reparação do contra molhe evitou os trabalhos adicionais de preparação necessários no molhe principal, mostrando ser uma solução igualmente eficaz, porém economicamente mais interessante.

A execução faseada das obras de reabilitação - feita com a retirada parcial dos elementos de proteção do molhe, seguida do correspondente reperfilamento do manto e recolocação dos blocos de betão no troço em questão - propiciou uma maior segurança à estrutura, pois, mesmo no caso de ocorrência de uma tempestade durante a execução dos trabalhos, a sua integridade nunca seria posta em causa, ainda que existisse um troço sem os blocos de proteção.

Além disso, a opção pela execução da reabilitação dos molhes por etapas, correspondendo cada uma delas a um troço com 
cerca de 30 metros de extensão, proporcionou uma melhor gestão do estaleiro da obra, visto que muitas vezes é difícil dispor de espaço suficiente para o armazenamento dos volumosos blocos de betão a serem empregues nas obras de reparação.

Outra opção que se pode considerar acertada, tanto em termos económicos quanto técnicos, foi a da extração de rocha de um filão basáltico existente na própria Ilha do Porto Santo, ao invés do emprego de um tipo de rocha menos capaz ou do recurso ao transporte de rocha basáltica extraída na vizinha llha da Madeira.

$O$ reperfilamento do enrocamento com rochas basálticas, em lugar das rochas sedimentares antes existentes, conferiu ao manto de proteção da estrutura de acostagem uma maior resistência à ação das ondas e às forças de compressão provocadas pelos blocos de betão, aumentando com isto a sua durabilidade comparativamente com a solução anterior.

Além do emprego de rochas basálticas, pode destacar-se como ponto favorável, tanto em termos ambientais quanto económicos, a reutilização, no enrocamento, dos tetrápodes préexistentes que se encontravam danificados, tendo sido tais blocos partidos de modo a se adequarem às especificações do projeto.

Para finalizar, e sendo a proteção do ambiente e a preservação da paisagem natural fatores fundamentais para o turismo, que é a base da economia da Ilha do Porto Santo, cabe ainda ressaltar como ação igualmente positiva, nomeadamente do ponto de vista ambiental e paisagístico, o cuidado em proceder ao aterro do local de extração das rochas basálticas, de modo a manter um perfil idêntico ao anterior à exploração.

\section{AGRADECIMENTOS}

Os autores desejam expressar os seus sinceros agradecimentos à ETERMAR - Engenharia e Construção, S.A., nomeadamente à sua Delegação no Funchal, e em particular aos Engenheiros Luís Madeira Teixeira e Ricardo Quaresma Nunes, pela informação, documentação e fotografias facultadas e pelo apoio dispensado para a realização deste estudo.

\section{REFERÊNCIAS BIBLIOGRÁFICAS}

ALFREDINI, P.; ARASAKI, E. Obras e gestão de portos e costas. 2. ed. São Paulo: Edgard Blücher, 2009.

BROWN, J. M.; SOUZA, A. J.; WOLF, J. Surge modelling in the eastern Irish Sea: present and future storm impact. Ocean Dynamics, v. 60, p. 227-236, 2010.

CARVALHO, A. M. G. de; BRANDÃO, J. M. Geologia do arquipélago da Madeira. Lisboa: Museu Nacional de História Natural, 1991.

CERC. Shore protection manual. 4. ed. Vicksburg, MS: U.S. Army Corps of Engineers, Coastal Engineering Research Center, 1984. v. 1.

CIRIA; CUR; CETMEF. The Rock Manual - The use of rock in hydraulic engineering. 2. ed. London: CIRIA, 2007.

CROPPER, T. E.; HANNA, E. An analysis of the climate of Macaronesia, 1865-2012. International Journal of Climatology, v. 34, p. 604-622, 2014.

ETERMAR. Obras Portuárias - Porto Santo: Grande reparação do molhe principal do porto de Porto Santo Setúbal, Portugal: ETERMAR - Engenharia e Construção, 2011.

FABIÃO, J. P. F. Estabilidade hidráulica do manto de quebra-mares de taludes: Estudo em modelo físico. Dissertação (Mestrado em Engenharia Civil). Instituto Superior Técnico, Universidade Técnica de Lisboa, Lisboa, 2012.

FRAGOSO, M.; TRIGO, R. M.; PINTO, J. G.; LOPES, S. LOPES, A.; ULBRICH, S.; MAGRO, C. The 20 February 2010 Madeira flash-floods: synoptic analysis and extreme rainfall assessment. Natural Hazards and Earth System Sciences, v. 12, p. 715-730, 2012.

LIN, P. Numerical modeling of water waves. New York: Taylor \& Francis, 2008.

LLORIS, D.; RUCABADO, D.; FIGUEROA, H. Biogeography of the Macaronesian ichtyofauna (The Azores, Madeira, the Canary Islands, Cape Verde and the African Enclave). Boletim do Museu Municipal do Funchal, v. 43, p. 191-241, 1991.

MAI, S.; OHLE, N.; DAEMRICH, K.-F. Numerical simulation of wave propagation compared to physical modeling. In: HYDROLAB: WORKSHOP ON EXPERIMENTAL RESEARCH AND SYNERGY EFFECTS WITH MATHEMATICAL MODELS, 1999, Hannover, Germany. Proceedings... Hannover: Coastal Research Centre, 1999. p. 217-226.

OH, S.-H.; SUH, K.-D.; SON, S. Y.; LEE, D. Y. Performance comparison of spectral wave models based on different governing equations including wave breaking. KSCE Journal of Civil Engineering, v. 13, p. 75-84, 2009. 
PILARCZYK, K. W. Geosynthetics and geosystems in hydraulic and coastal engineering. Rotterdam: A. A. Balkema, 2000.

PITA, C. Dimensionamento hidráulico do manto resistente de quebra-mares de talude. Memória $\mathrm{n}$ 670 . Lisboa: LNEC, 1986.

RAMOS, R. L. T. A. Potencialidades e condicionalismos físicos do desenvolvimento portuário da Região Autónoma da Madeira: Caso de estudo - ampliação do porto do Funchal. Dissertação (Mestrado em Engenharia Civil) - Faculdade de Engenharia. Universidade do Porto, Porto, 2009.

REIS, M. T.; SANTOS., J. A.; NEVES, D. R.; CAPITÃO, R.; FORTES, C. J. Avaliação da probabilidade de ocorrência de galgamentos não admissíveis no posto 2 do terminar de granéis líquidos do porto de Sines, Territorium, v. 21, p. 95-113, 2014.

ROCHA, A.; SILVA, J.; SOARES, H.; ABENTA, J.; ALMEIDA, F.; GOMES, C. Geologia, génese e dinâmica da areia de praia da ilha do Porto Santo: o sistema de informação geográfica. In: ENCONTRO DE UTILIZADORES DE SISTEMAS DE INFORMAÇÃO GEOGRÁFICA, 7., 2002, Oeiras, Portugal. Actas... Lisboa: Instituto Geográfico Português, 2002. p. 1-25.

SALA, I.; CALDEIRA, R. M. A.; ESTRADA-ALLIS, S. N.; E. FROUFE, E.; COUVELARD, $X$. Lagrangian transport pathways in the northeast Atlantic and their environmental impact. Limnology and Oceanography: Fluids and Environments, v. 3, p. 40-60, 2013.

SETH - SOCIEDADE DE EMPREITADAS E TRABALHOS HIDRÁULICOS, S.A., Perfil da empresa - Engenharia costeira e portuária: Grande reparação do molhe principal do porto de Porto Santo, Porto Santo (Arquipélago da Madeira). Queijas, Portugal: Seth S.A., 2016.

SILVA, J. B. P. da. Areia de praia da ilha do Porto Santo: geologia, génese, dinâmica e propriedades medicinais. Tese (Doutoramento em Geociências). Universidade de Aveiro, Aveiro, Portugal, 2002.

SOUSA, N. M. B. de. Obras marítimas de acostagem: o caso do porto de abrigo da ilha do Porto Santo. Dissertação (Mestrado em Engenharia Civil). Universidade da Madeira, Funchal, Portugal, 2011.

TAVEIRA-PINTO, F.; NEVES, A. C. A importância da consideração do carácter irregular da agitação marítima no dimensionamento de quebramares de taludes. Engenharia Civil, v. 16, p. 95-111, 2003.

TAYLOR, D.; DAVIES, K. Engineering the rehabilitation of reinforced concrete port structures. In: PIANC-AIPCN CONGRESS, 30., 2002, Sydney, Australia. Proceedings... Sydney, NSW: Institution of Engineers. p. 482-489.

THORESEN, C. A. Port design's handbook. 3. ed. London: ICE Publishing, 2014.

TSINKER, G. P. Port engineering: Planning, construction, maintenance, and security. Hoboken, NJ: Wiley, 2004.
WW - CONSULTORES DE HIDRÁULICA E OBRAS MARÍTIMAS. Inspecção detalhada do molhe principal do porto do Porto Santo. Funchal, Portugal: Portos da Madeira, 2005.

WW - CONSULTORES DE HIDRÁULICA E OBRAS MARÍTIMAS. Concurso público internacional para a empreitada grande reparação do molhe principal do porto do Porto Santo - v. 3: Projecto de execução. Funchal, Portugal: Portos da Madeira, 2006. 